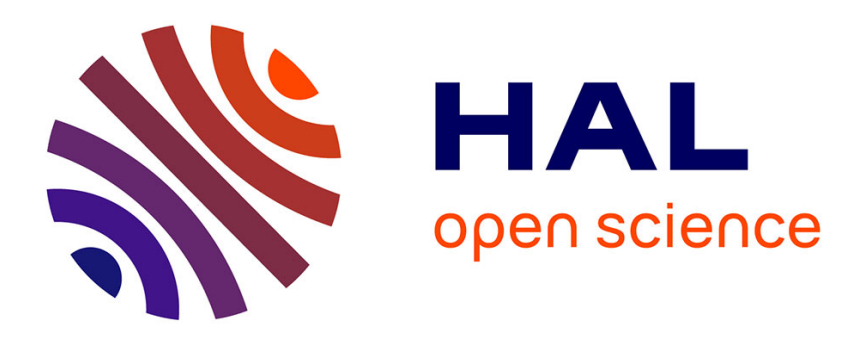

\title{
A normalised seawater strontium isotope curve and the Neoproterozoic-Cambrian chemical weathering event
}

\author{
G. A. Shields
}

\section{To cite this version:}

G. A. Shields. A normalised seawater strontium isotope curve and the Neoproterozoic-Cambrian chemical weathering event. eEarth Discussions, 2007, 2 (1), pp.69-84. hal-00298250

\section{HAL Id: hal-00298250 \\ https://hal.science/hal-00298250}

Submitted on 22 Mar 2007

HAL is a multi-disciplinary open access archive for the deposit and dissemination of scientific research documents, whether they are published or not. The documents may come from teaching and research institutions in France or abroad, or from public or private research centers.
L'archive ouverte pluridisciplinaire HAL, est destinée au dépôt et à la diffusion de documents scientifiques de niveau recherche, publiés ou non, émanant des établissements d'enseignement et de recherche français ou étrangers, des laboratoires publics ou privés. 


\section{A normalised seawater strontium isotope curve and the Neoproterozoic-Cambrian chemical weathering event}

\section{G. A. Shields}

Geologisch-Paläontologisches Institut, Westfälische-Wilhelms Universität, Correnstr. 24, 48149 Münster, Germany

Received: 9 February 2007 - Accepted: 17 March 2007 - Published: 22 March 2007

Correspondence to: G. A. Shields (gshields@uni-muenster.de)

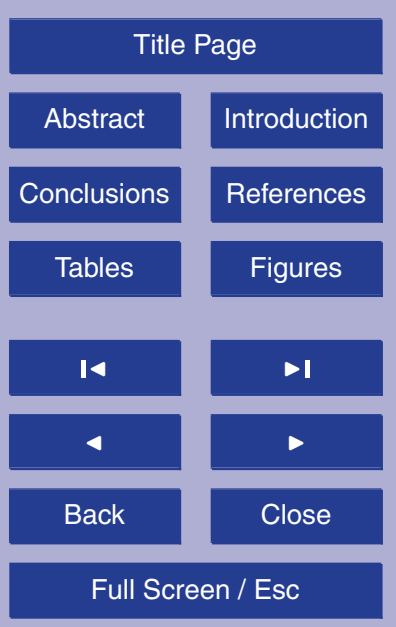

Printer-friendly Version

Interactive Discussion 


\section{Abstract}

The strontium isotope composition of seawater has varied over geological time in response to changes in the rates of continental weathering relative to ocean crust alteration. However, the potential of the seawater ${ }^{87} \mathrm{Sr} /{ }^{86} \mathrm{Sr}$ curve to trace globally inte5 grated chemical weathering rates has not been fully realised because ocean ${ }^{87} \mathrm{Sr} /{ }^{86} \mathrm{Sr}$ is also strongly influenced by the isotopic evolution of $\mathrm{Sr}$ sources to the ocean. A first attempt is made here to normalise the seawater ${ }^{87} \mathrm{Sr} /{ }^{86} \mathrm{Sr}$ curve to plausible trends in the ${ }^{87} \mathrm{Sr} /{ }^{86} \mathrm{Sr}$ ratios of the three major Sr sources: carbonate dissolution, silicate weathering and submarine hydrothermal exchange. The normalised curve highlights the

10 Neoproterozoic-Cambrian interval as a period of exceptionally high chemical weathering rates, which can be linked to increased nutrient availability, bioproductivity and oxygenation of Earth's surface environment. Use of normalised seawater ${ }^{87} \mathrm{Sr} /{ }^{86} \mathrm{Sr}$ curves will, it is hoped, help to improve future geochemical models of Earth System dynamics.

\section{Introduction}

Strontium in modern seawater $\left({ }^{87} \mathrm{Sr} /{ }^{86} \mathrm{Sr} \sim 0.709\right)$ derives from two major sources: the submarine, chemical alteration of ocean crust $\left({ }^{87} \mathrm{Sr} /{ }^{86} \mathrm{Sr} \sim 0.703\right.$ : Hofmann, 1997) and the subaerial, chemical weathering of the continental crust and its sedimentary cover $\left({ }^{87} \mathrm{Sr} /{ }^{86} \mathrm{Sr} \sim 0.712\right.$ : Palmer and Edmond, 1989; Peucker-Ehrenbrink and Miller, 2006). 20 The ${ }^{87} \mathrm{Sr} /{ }^{86} \mathrm{Sr}$ signatures of these two isotopic end members indicate that about twice as much ocean $\mathrm{Sr}$ derives from river runoff (RR) than from hydrothermal exchange (MI). Because seafloor spreading rates, which determine ocean crust production, are not considered to change erratically over geological time (Rowley, 2002), attempts have been made to use the marine carbonate-based seawater ${ }^{87} \mathrm{Sr} /{ }^{86} \mathrm{Sr}$ curve to trace changes in globally integrated chemical weathering rates (Francois and Walker, 1992; Kennedy et al., 2006). This approach is complicated, however, by the fact that seawater
2, 69-84, 2007

\section{A normalised \\ seawater strontium \\ isotope curve}

G. A. Shields

\section{Title Page}

Abstract

Introduction

Conclusions

Tables

References

Figures

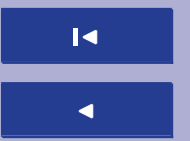

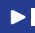

Back

$\triangleright$

\section{Close}

Full Screen / Esc

Printer-friendly Version

Interactive Discussion 
${ }^{87} \mathrm{Sr} /{ }^{86} \mathrm{Sr}$ is affected not only by changes in the rates of continental weathering relative to sea-floor spreading but also by variations in the isotopic composition of river runoff and the upper mantle. Uncertainties in the ${ }^{87} \mathrm{Sr} /{ }^{86} \mathrm{Sr}$ of past river runoff, in particular, undermine the potential of the seawater ${ }^{87} \mathrm{Sr} /{ }^{86} \mathrm{Sr}$ curve to be an unambiguous tracer 5 of chemical weathering (Veizer and Mackenzie, 2003).

The ${ }^{87} \mathrm{Sr} /{ }^{86} \mathrm{Sr}$ signature of $\mathrm{RR}$ is a function of the ratio between carbonate and silicate weathering rates with respect to Sr. Although it is widely held that carbonate weathering is the dominant source of $\mathrm{Sr}$ in river runoff (75\%: Brass, 1976; 67\%: Berner and Rye, 1992; 78\%: Veizer and Mackenzie, 2003), variations in the ${ }^{87} \mathrm{Sr} /{ }^{86} \mathrm{Sr}$ ratio of the carbonate component in river runoff have generally not been considered in interpretations of first order seawater ${ }^{87} \mathrm{Sr} /{ }^{86} \mathrm{Sr}$ evolution. Here I propose plausible, but not incontrovertible evolutionary trends for the three major Sr sources to the ocean: 1) submarine, elemental exchange with ocean crust (MI); 2) subaerial, chemical weathering of silicate minerals (RRS); and 3) subaerial dissolution of marine carbonate (and 5 marine sulphate) rocks (RRC), in order to illustrate how the seawater ${ }^{87} \mathrm{Sr} /{ }^{86} \mathrm{Sr}$ curve can be normalised against the isotopic evolution of $\mathrm{Sr}$ sources to the ocean. The use of more sophisticated, normalised seawater ${ }^{87} \mathrm{Sr} /{ }^{86} \mathrm{Sr}$ curves will it is hoped lead to improved biogeochemical models of the exogenic Earth system.

\section{Evolving ${ }^{87} \mathrm{Sr} /{ }^{86} \mathrm{Sr}$ signatures of $\mathrm{Sr}$ sources to the ocean}

20 1) Exchange between seawater and ocean crust (MI in Fig. 1) occurs generally at midocean ridges and ridge flanks and supplies Sr to the ocean that inherits the isotopic composition of its magmatic precursor, the depleted mantle (Spooner, 1976), which is 0.703 (Hofmann, 1997). Modern MI represents the accumulation of radiogenic ${ }^{87} \mathrm{Sr}$ in the depleted mantle, which deviated early in Earth history from the bulk earth ${ }^{87} \mathrm{Sr} /{ }^{86} \mathrm{Sr}$ trend as a result of the preferential incorporation of $\mathrm{Rb}$ over $\mathrm{Sr}$ into the crust. This process led to a lessening of the rate of ${ }^{87} \mathrm{Sr} /{ }^{86} \mathrm{Sr}$ increase in MI, either since the onset of modern tectonics close to the Archaean-Proterozoic boundary (O'Nions, 1979) or

2, 69-84, 2007
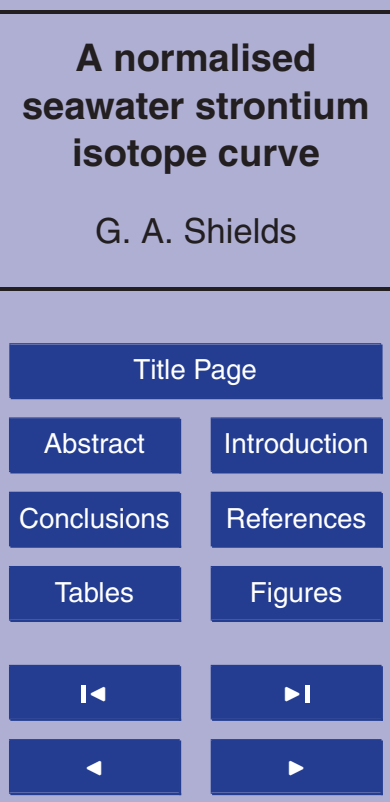

Back itle Page

Introduction References

Figures

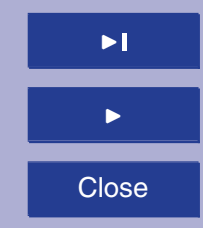

Full Screen / Esc

Printer-friendly Version

Interactive Discussion 
according to some estimates already by c. 3.8 Ga (McCulloch, 1994).

2) Silicate weathering (RRS in Fig. 1) supplies relatively radiogenic Sr to the oceans by virtue of the high $\mathrm{Rb} / \mathrm{Sr}$ ratios of most rock-forming silicate minerals and the high mean age of the Upper Continental Crust (UCC). However, it has been noted by several 5 authors that the average isotopic composition of surface rocks exposed to weathering appears to be less radiogenic than would normally be expected simply from the radioactive decay of ${ }^{87} \mathrm{Rb}$, e.g. $\sim 0.716$ (Goldstein and Jacobsen, 1988) instead of the expected value of $>0.730$ (Veizer and Mackenzie, 2003), meaning that radiogenic $\mathrm{Sr}$ has been lost from the silicate pile over time (Goldstein, 1988). The mean ${ }^{87} \mathrm{Sr} /{ }^{86} \mathrm{Sr}$ ra10 tio of the detrital silicate component in modern rivers is 0.7178 (Bickle, 1994), and this is accepted here to be the best estimate for the isotopic signature of silicate-derived, dissolved $\mathrm{Sr}$ in modern rivers (RRS). Tracing the ${ }^{87} \mathrm{Sr} /{ }^{86} \mathrm{Sr}$ ratio of RRS into the past is difficult because it depends not only on the isotopic evolution of the upper crust but also on the relative susceptibility to weathering, age and $\mathrm{Sr}$ content of the various silicate minerals that make up the exposed parts of the crust.

The Sr isotopic evolution of crustal silicates would normally be expected to deviate from that of the depleted mantle as a mirror image, albeit with a steeper gradient, taking into account the relative size differences of these two Sr reservoirs (O'Nions et al., 1979). However, there is a tendency for $\mathrm{Rb}$ and $\mathrm{Sr}$ to partition into different mineral phases in the surface environment, which complicates any simplistic trend. Sr is leached preferentially from silicates during chemical weathering and tends to accumulate conservatively in seawater, whereas $\mathrm{Rb}$, although soluble, has a strong affinity to the clay silicate fractions of both soils and fine-grained marine sediments. Although some current thinking (e.g. Kemp et al., 2006) considers that any such surface effects were more than compensated for by the preferential partitioning of $\mathrm{Rb}$ into granitic melts during partial melting and fractional crystallisation, there is no consensus on the evolution of crustal ${ }^{87} \mathrm{Sr} /{ }^{86} \mathrm{Sr}$ and it is not the aim of this article to contribute to this complex debate. Accordingly, the RRS trend in Fig. 1a is an idealised curve; however, this should not greatly affect the conclusions of the present article. For example, were

2, 69-84, 2007
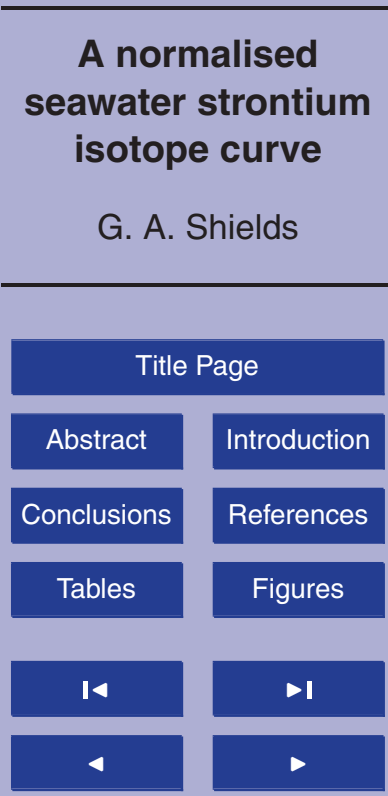

Back Title Page

Introduction References Figures

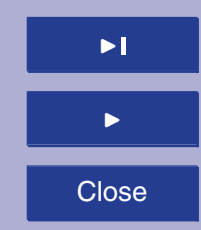

Full Screen / Esc

Printer-friendly Version

Interactive Discussion 
I to assume unchanging $\mathrm{RRS}^{87} \mathrm{Sr} /{ }^{86} \mathrm{Sr}$ through time (Goldstein, 1988), this would only dampen the major features of the normalised curve shown in Fig. 1b but not eliminate them.

3) The dissolution of carbonate rocks (limestones and dolomites) and evaporitic sul5 phates (gypsum, anhydrite) is considered to be the major source of $\mathrm{Sr}$ to the oceans (Brass, 1976) by virtue of the high Sr contents and high solubility of those minerals. The isotopic signature of this largely carbonate source today $(\sim 0.708)$ is close to the range of Phanerozoic seawater ( 0.707-0.709) and so changes in the rates and isotopic composition of the carbonate weathering flux (RRC) are widely disregarded in 10 interpretations of ocean ${ }^{87} \mathrm{Sr} /{ }^{86} \mathrm{Sr}$ trends (Veizer and Mackenzie, 2003). However, the ${ }^{87} \mathrm{Sr} /{ }^{86} \mathrm{Sr}$ of RRC is largely dependent on past seawater ${ }^{87} \mathrm{Sr} /{ }^{86} \mathrm{Sr}$ and so will have evolved considerably over time. According to recent estimates (Peucker-Ehrenbrink and Miller, 2006), about half of all sediments undergoing weathering at the Earth's surface are younger than $0.25 \mathrm{Ga}$, while the rest must be aged between 0.25 and $3.5 \mathrm{Ga}$ 5 with a strong bias towards younger Phanerozoic sedimentary rocks Assuming that this skewed age distribution has remained the same since carbonate platforms first became abundant around $2.5 \mathrm{Ga}$, the ${ }^{87} \mathrm{Sr} /{ }^{86} \mathrm{Sr}$ of RRC can be traced back through time (Fig. 1a). Clearly, the changing seawater ${ }^{87} \mathrm{Sr} /{ }^{86} \mathrm{Sr}$ will have exerted considerable control over the isotopic evolution of river runoff independently of the age distribution of 20 rocks undergoing weathering or crustal evolution. Significantly, seawater and predicted $\mathrm{RRC}{ }^{87} \mathrm{Sr} /{ }^{86} \mathrm{Sr}$ reached a maximum divergence of $\sim 0.004$ at around $0.5 \mathrm{Ga}$ (Middle Cambrian-Early Ordovician).

\section{River runoff versus mantle input through time}

Modern-day river runoff ${ }^{87} \mathrm{Sr} /{ }^{86} \mathrm{Sr}$, at 0.7124 (Palmer and Edmond, 1989; Peucker25 Ehrenbrink and Miller, 2006), reflects a mixture of Sr from the weathering of carbonates $\left({ }^{87} \mathrm{Sr} /{ }^{86} \mathrm{Sr}=0.7077\right)$ and silicates $\left({ }^{87} \mathrm{Sr} /{ }^{86} \mathrm{Sr}=0.7178\right)$. Using these estimates, approximately $55 \%$ of the $\mathrm{Sr}$ in modern rivers derives from the weathering of carbonate
2, 69-84, 2007
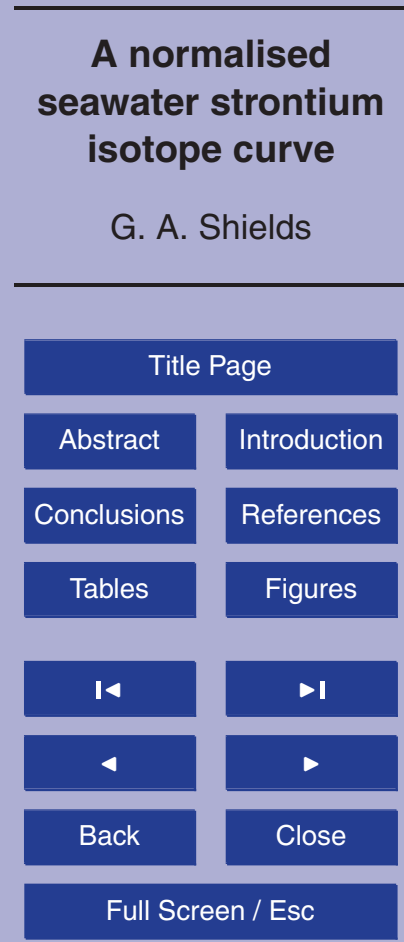

Printer-friendly Version

Interactive Discussion 
minerals (cf. 60\%: Bickle, 1994). This appears to be a conservative estimate, being considerably lower than the initially proposed $75 \%$ ratio (Brass, 1976) and is also lower than the $67 \%$ ratio used in published models of the exogenic Sr isotope system (Francois and Walker, 1992; Berner and Rye, 1992). In this regard, it can be argued that the 5 estimated isotopic composition of RRW is only a minimum constraint as marine carbonate and evaporite minerals generally incorporate more radiogenic Sr during diagenetic alteration. The isotopic composition of the modern RRS flux is not well constrained. In particular, the assumption that the $\mathrm{Sr}$ isotopic composition of detrital silicates accurately represents that of the dissolved Sr component (Bickle, 1994) may overestimate 10 the ${ }^{87} \mathrm{Sr} /{ }^{86} \mathrm{Sr}$ of RRS due to the generally greater susceptibility to weathering of less radiogenic silicate minerals.

In order to use the seawater ${ }^{87} \mathrm{Sr} /{ }^{86} \mathrm{Sr}$ curve as a measure of changes in river runoff (RR) versus mantle Sr input (MI), I have first estimated the ${ }^{87} \mathrm{Sr} /{ }^{86} \mathrm{Sr}$ of RR by assuming that the modern ratio of $45: 55$ between the silicate and carbonate weathering fluxes 15 has remained the same throughout the past $2.5 \mathrm{Ga}$. This assumption appears to be somewhat valid as the resultant curve of river runoff ${ }^{87} \mathrm{Sr} /{ }^{86} \mathrm{Sr}$ (Fig. 1a) does not cross even the highest peaks of the seawater ${ }^{87} \mathrm{Sr} /{ }^{86} \mathrm{Sr}$ trend. Indeed, the relative influence of carbonate weathering on the isotopic composition of river runoff is likely to have been even greater in the geological past. This is because carbonate dissolution is 20 not constrained directly by the endogenic (volcanic and metamorphic) $\mathrm{CO}_{2}$ flux unlike silicate weathering, and was probably favoured in the geological past due to the greater acidity of rainfall caused by higher atmospheric $\mathrm{CO}_{2}$ (Kasting and Siefert, 2004), while the absence of land plants and eukaryotic soil biota meant that silicate weathering efficiency was likely depressed during the Precambrian relative to today (Lenton and Watson, 2004). The flux of Sr derived from carbonate dissolution seems therefore likely to have dominated over that from silicate weathering for as long as carbonate platforms have been abundant on Earth, i.e. since the early Proterozoic or possibly the late Archean. The relative influence of river runoff versus mantle input (Fig. 1b) can now be estimated by considering seawater ${ }^{87} \mathrm{Sr} /{ }^{86} \mathrm{Sr}$ to be a binary mixture of RR and

2, 69-84, 2007

\section{A normalised seawater strontium isotope curve \\ G. A. Shields}

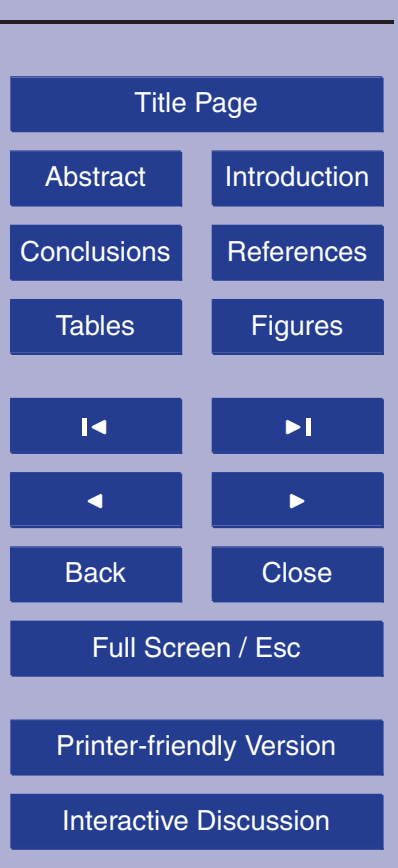


MI.

The resultant normalised ${ }^{87} \mathrm{Sr} /{ }^{86} \mathrm{Sr}$ curve in figure $1 \mathrm{~b}$ displays some significant deviations from the seawater ${ }^{87} \mathrm{Sr} /{ }^{86} \mathrm{Sr}$ curve from which it was derived, and therefore from previous estimates of river runoff versus mantle input. These differences are not 5 particularly sensitive to the age model chosen for carbonate sediments undergoing weathering or to the evolutionary model for the silicate weathering component in rivers.

Most importantly, there is no longer any evidence for a stepwise change in the ${ }^{87} \mathrm{Sr} /{ }^{86} \mathrm{Sr}$ base-level (Fig. 1a) across the Proterozoic-Phanerozoic transition, which had been interpreted previously to indicate an irreversible shift in chemical weather10 ing rates due to the evolution of soil biota on the continents (Kennedy et al., 2006). The shift in the base-level noted by those authors can instead be explained by increases in the ${ }^{87} \mathrm{Sr} /{ }^{86} \mathrm{Sr}$ ratios of the Phanerozoic carbonate weathering and mantle fluxes. Another feature of note is the relative deflation of the Cenozoic ${ }^{87} \mathrm{Sr} /{ }^{86} \mathrm{Sr}$ peak compared with the previously equivalent Cambrian ${ }^{87} \mathrm{Sr} /{ }^{86} \mathrm{Sr}$ peak. The significance of 15 the Neoproterozoic-Cambrian rise in seawater ${ }^{87} \mathrm{Sr} /{ }^{86} \mathrm{Sr}$ can only be fully appreciated when one considers that the ${ }^{87} \mathrm{Sr} /{ }^{86} \mathrm{Sr}$ compositions of both the $\mathrm{MI}$ and the RRC fluxes would have been considerably lower during the Neoproterozoic-Cambrian interval.

\section{The Neoproterozoic-Cambrian chemical weathering event}

The Neoproterozoic-Cambrian rise in seawater ${ }^{87} \mathrm{Sr} /{ }^{86} \mathrm{Sr}$ (normalised or otherwise) can 20 be explained by one or more of four different factors: 1) an increase in the ${ }^{87} \mathrm{Sr} /{ }^{86} \mathrm{Sr}$ ratio (and age) of the rocks undergoing weathering above that predicted by the idealised trend shown in figure 1a; 2) a decrease in the mantle Sr input and/or seafloor spreading rates; 3) an increase in overall continental weathering rates; and/or 4) an increase in the silicate/carbonate weathering ratio. As I attempt to show below, the most likely explanation involves a combination of options 3 and 4 .

The excellent correlation between the normalised seawater ${ }^{87} \mathrm{Sr} /{ }^{86} \mathrm{Sr}$ curve and seawater $\delta^{34} S$ (Fig. 1b) implies that absolute fluxes and not the isotopic evolution of those

2, 69-84, 2007

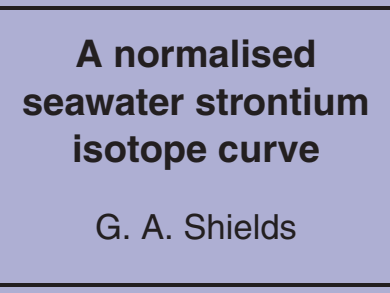

Title Page

Abstract

Introduction

Conclusions

Tables

References

Figures

14

14

$\Delta \mathbf{I}$

4

Back

Close

Full Screen / Esc

Printer-friendly Version

Interactive Discussion 
fluxes led to first-order ${ }^{87} \mathrm{Sr} /{ }^{86} \mathrm{Sr}$ trends. This is because the seawater $\delta^{34} \mathrm{~S}$ record is thought to reflect changes in the biogeochemical cycling of sulphur (Strauss, 1999), and so ought to be independent of changes in the ${ }^{87} \mathrm{Sr} /{ }^{86} \mathrm{Sr}$ isotopic ratios of rocks exposed to weathering. In this regard, although tectonic upheavals can feasibly change 5 the globally integrated age (Halverson et al., 2007), and therefore ${ }^{87} \mathrm{Sr} /{ }^{86} \mathrm{Sr}$ of rocks undergoing weathering, it seems that such changes only controlled second order variations in the seawater ${ }^{87} \mathrm{Sr} /{ }^{86} \mathrm{Sr}$ curve. This conclusion is consistent with the widely held interpretation that the Neoproterozoic-Cambrian interval was a time of $\mathrm{CO}_{2}$ drawdown (and $\mathrm{O}_{2}$ increase) caused by elevated weathering rates (Derry et al., 1992). A $50 \%$ de10 crease in the mantle input flux would have been sufficient to cause the NeoproterozoicCambrian rise. However, such a large, sustained decrease in seafloor spreading rates seems improbable during a period of exceptionally rapid continental reconfiguration, generally high sea-level and widespread rifting (Kirschvink et al., 1997). The most plausible explanation for the Neoproterozoic-Cambrian rise is therefore a sustained increase in overall continental and/or silicate weathering rates.

Times of low continental influence on ocean ${ }^{87} \mathrm{Sr} /{ }^{86} \mathrm{Sr}$ correlate with the existence of the supercontinents Rodinia and Pangaea, while their break-up is associated with sustained increases in continental influence on the ocean Sr isotope budget. One possible explanation for this connection is that increased rates of physical weathering due 20 to tectonic uplift led to higher overall chemical weathering rates during times of supercontinent break-up and microcontinent collision (Jacobsen and Kaufman, 1999; Squire et al., 2006). In support of this interpretation, the normalised ${ }^{87} \mathrm{Sr} /{ }^{86} \mathrm{Sr}$ curve correlates well with sediment flux rates (Hay et al., 2001) and rifting events (D. S. Bradley, personal communication), while the rise to peak ${ }^{87} \mathrm{Sr} /{ }^{86} \mathrm{Sr}$ values correlates with the formation of 25 huge mountain chains, such as the "Transgondwanan Supermountain" (Squire et al., 2006). However, sustained increases in silicate weathering rates are only thought to be possible so long as increased $\mathrm{CO}_{2}$ fluxes accompany them (Walker et al., 1981), in which case increased rates of $\mathrm{CO}_{2}$ degassing from carbonate metamorphism (Bickle, 1994) and granitisation during, may be relevant. Increases in the efficiency of sili-

2, 69-84, 2007
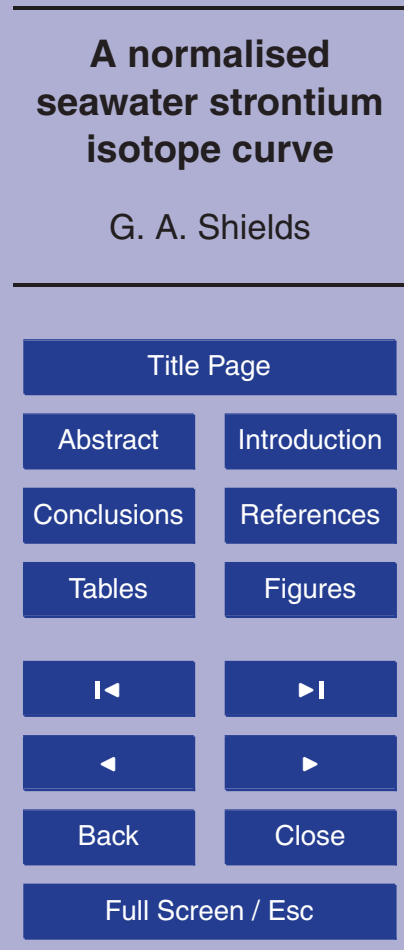

Printer-friendly Version

Interactive Discussion 
cate weathering may also have occurred during the Neoproterozoic-Cambrian interval, caused by the evolution of soil biota (Kennedy et al., 2006; Lenton and Watson, 2004); however, any such irreversible change in the silicate versus carbonate weathering ratio must have been accompanied by a decline in overall continental weathering rates after 5 the Cambrian Period.

It has long been noted that the long-term seawater ${ }^{87} \mathrm{Sr} /{ }^{86} \mathrm{Sr}$ record correlates positively with $\delta^{34} \mathrm{~S}$ during the Phanerozoic and negatively with $\delta^{13} \mathrm{C}$ and this has been taken to indicate a tectonic control on global C- and S-biogeochemical cycles (Veizer et al., 1999). The normalised ${ }^{87} \mathrm{Sr} /{ }^{86} \mathrm{Sr}$ curve improves the correlation with $\delta^{34} \mathrm{~S}$ and 10 extends it back to c. $800 \mathrm{Ma}$ (Fig. 1b), which implies that increased chemical weathering rates led to higher rates of sulphate reduction (and pyrite burial), presumably linked to higher rates of organic carbon degradation. The alternative proposition that rates of weathering might control seawater $\delta^{34} S$ directly by changing the riverine sulphate flux can be excluded as this would lead to an inverse correlation between the two iso15 topic parameters (Bottrell and Newton, 2006). Correlation between globally integrated organic degradation rates and enhanced chemical weathering rates is consistent with the notion that bioproductivity is limited over geological time scales by the availability of phosphorus (Lenton and Watson, 2000), which can only be derived from the weathering of rocks. The onset of the ${ }^{87} \mathrm{Sr} /{ }^{86} \mathrm{Sr}$ rise also marks the beginning of unusually high

$\delta^{13} \mathrm{C}$ values that were set to become characteristic of the later Neoproterozoic (Halverson et al., 2007). Thus it would appear that this sustained, weathering-driven increase in productivity also led to higher rates of organic carbon burial, and so presumably was the major driver towards the further oxygenation of the surface environment at this time (Derry et al., 1992).

25 Recent studies have emphasised the role of terrestrial biota in increasing both $\mathrm{P}$ weathering rates (Lenton and Watson, 2004) and overall silicate weathering rates (Kennedy et al., 2006) during the Neoproterozoic-Cambrian interval. Although the evolution of terrestrial eukaryotes by $600 \mathrm{Ma}$ (Heckman et al., 2001; Yuan et al., 2005) may be one cause for the increase in weathering rates, their influence was clearly reversible

2, 69-84, 2007
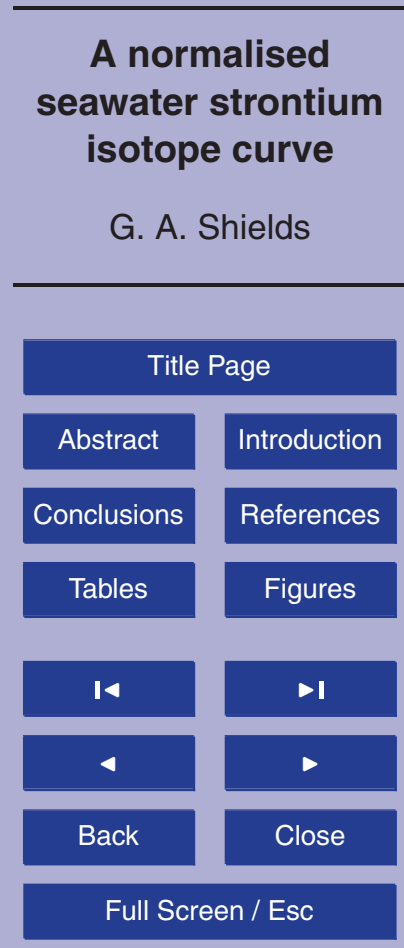

Printer-friendly Version

Interactive Discussion 
as seawater ${ }^{87} \mathrm{Sr} /{ }^{86} \mathrm{Sr}$ decreased steadily after its Late Cambrian peak. This may be due to the establishment of a new equilibrium between more efficient drawdown of atmospheric $\mathrm{CO}_{2}$ by silicate weathering and the endogenic $\mathrm{CO}_{2}$ flux. A similar scenario has been suggested to take place after the evolution of vascular land plants during the 5 later Palaeozoic, whereby the evolution of land plants is considered by some to have led to eutrophication, $\mathrm{CO}_{2}$ disequilibrium and the contemporaneous Permo-Carboniferous glaciations, and higher atmospheric oxygen levels (Lenton, 2001).

The existence of prolonged pulses of chemical weathering may explain the hitherto enigmatic age distribution of phosphorus-rich rocks on Earth. Sedimentary phosphorite rocks of economic importance have only been deposited during four intervals of Earth history (Shields et al., 2000). The c. 2.0 Ga Paleoproterozoic, Neoproterozoiclate Cambrian $(0.65-0.5 \mathrm{Ga})$ and mid-Cretaceous-Recent $(0.1-0.0 \mathrm{Ga})$ intervals, were true P-giant episodes (Fig. 1b) with phosphorus-rich rocks and related organic-rich strata distributed worldwide. The other major deposit, the Phosphoria Formation, is limited in areal distribution and formed during the Permian icehouse. All three P-giant episodes stand out as times of enhanced chemical weathering rates according to the normalised ${ }^{87} \mathrm{Sr} /{ }^{86} \mathrm{Sr}$ record.

This new reading of the seawater ${ }^{87} \mathrm{Sr} /{ }^{86} \mathrm{Sr}$ record suggests that its first order trend records changes in globally integrated chemical weathering rates, while its second or20 der features are more likely to be related to changes in the isotopic composition of source fluxes (Jones and Jenkyns, 2001). By association, long-term trends in seawater $\delta^{34} S$ reflect variations in ocean productivity driven by changes in the riverine nutrient flux. Four possible chemical weathering events can be recognised in Earth history, representing periods of disequilibrium and elevated organic productivity. Of these, 25 the Neoproterozoic-Cambrian interval stands out as a time when increased chemical weathering rates pushed the Earth System to a new state characterised by higher $\mathrm{O}_{2}$ and lower $\mathrm{CO}_{2}$ and accompanied by the appearance of new forms of animal, plant and fungal life.
2, 69-84, 2007

\section{A normalised \\ seawater strontium \\ isotope curve}

G. A. Shields

\section{Title Page}

Abstract

Introduction

Conclusions

References

Tables

Figures

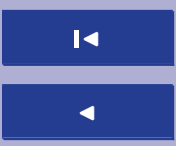

$\Delta$

Back

$\checkmark$

Close

Full Screen / Esc

Printer-friendly Version

Interactive Discussion 


\section{Conclusions}

The carbonate dissolution component to river runoff has never been considered in interpretations of first order trends in the seawater ${ }^{87} \mathrm{Sr} /{ }^{86} \mathrm{Sr}$ curve despite the dominance of this component today and the certainty that it has must have changed greatly over

5 Earth history. When predictable trends in this parameter and other factors influencing seawater ${ }^{87} \mathrm{Sr} /{ }^{86} \mathrm{Sr}$ are considered, it appears that there was a reversible trend towards unusually high rates of chemical weathering during the late Neoproterozoic and Cambrian. These high rates may help to explain the evidence for eutrophication around this time in the form of massive phosphorite deposits, black shales, high organic carbon burial rates (high $\delta^{13} \mathrm{C}$ ) and high organic degradation rates (high $\delta^{34} \mathrm{~S}$ ). Sustained high chemical weathering rates and related $\mathrm{CO}_{2}$ drawdown are both consistent with the notion that Earth's exogenic system became oxygenated over this interval, thus paving the way for the further evolution of animals.

\section{References}

Berner, R. A. and Rye, D. M.: Calculation of the Phanerozoic strontium isotope record of the oceans from a carbon cycle model, Am. J. Sci., 292, 136-148. 1992.

Bickle, M. J.: The role of metamorphic decarbonation reactions in returning strontium to the silicate sediment mass, Nature, 367, 699-704, 1994.

Bottrell, S. H. and Newton, R. J.: Reconstruction of changes in global sulphur cycling from marine sulphate isotopes, Earth Sci. Rev. 75, 59-83, 2006.

Brass, G. W.: The variation of the marine ${ }^{87} \mathrm{Sr} /{ }^{86} \mathrm{Sr}$ ratio during Phanerozonic time: interpretation using a flux model, Geochim. Cosmochim. Acta, 40, 721-730, 1976.

Derry, L. A., Kaufman, A. J., and Jacobsen, S. B.: Sedimentary cycling and environmental change in the Late Proterozoic: Evidence from stable and radiogenic isotopes, Geochim. 25 Cosmochim. Acta, 56, 1317-1329, 1992.

Francois, L. M. and Walker, J. C. G.: Modelling the Phanerozoic carbon cycle and climate: constraints from the ${ }^{87} \mathrm{Sr}{ }^{86} \mathrm{Sr}$ isotopic ratio of seawater, Am. J. Sci., 292, 81-135, 1992.
2, 69-84, 2007

\section{A normalised \\ seawater strontium \\ isotope curve}

G. A. Shields

\section{Title Page}

Abstract

Introduction

Conclusions

Tables

References

Figures

14

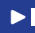

4

Back

$\triangleright$

Close

Printer-friendly Version

Interactive Discussion 
Goldstein, S. J. and Jacobsen, S. B.: Nd and Sr isotopic systematics of river water suspended material: Implications for crustal evolution, Earth Planet. Sci. Lett., 87, 249-265, 1988.

Goldstein, S. L.: Decoupled evolution of $\mathrm{Sr}$ and Nd isotopes in the continental crust and mantle, Nature, 336, 733-738, 1988.

5 Halverson, G., Dudas, F.Ö., A. C. Maloof, and Bowring, S. A.: Evolution of the ${ }^{87} \mathrm{Sr} /{ }^{86} \mathrm{Sr}$ composition of Neoproterozoic seawater, Palaeogeog. Palaeoclimat., Palaeoecol, in press, 2007.

Hay, W. W., Wold, C. N., Söding, E., and Flögel, S.: Evolution of sedimentary fluxes and ocean salinity, in: Geologic modelling and simulation: sedimentary systems, edited by: Merriam, D. F. and Davis, J. C., Kluwer Academic/Plenum Publishers, New York, pp. 153-167 (2001).

10 Heckman, D. S., Heckmann, D. S., Geiser, D. M., Eidell, B. R., et al.: Molecular evidence for the early colonization of land by plants and fungi, Science, 291, 1129-1133, 2001.

Hofmann, A. W.: Mantle geochemistry: the message from ocean volcanism, Nature, 385, 219229, 1997.

Hough, M. L., Shields, G. A., Evins, L. Z., Strauss, H., Henderson, R. A., and Mackenzie, S.: 15 A major sulphur isotope at c. $510 \mathrm{Ma}$ : a possible connection anoxia-extinction-volcanism connection during the Early-Middle Cambrian transition?, Terra Nova, 18, 257-263, 2006.

Jacobsen, S. B. and Kaufman, A. J.: The Sr, C and O isotopic evolution of Neoproterozoic seawater, Chem. Geol., 161, 37-57, 1999.

Jones, C. E. and Jenkyns, H. C.: Seawater Strontium Isotopes, Oceanic Anoxic Events, and Seafloor Hydrothermal Activity in the Jurassic and Cretaceous, Am. J. Sci., 312, 112-149, 2001.

Kamber, B. A. and Webb, G. M.: The geochemistry of late Archaean microbial carbonate: Implications for ocean chemistry and continental erosion history, Geochim. Cosmochim. Acta, 65, 2509-2525, 2001.

Kampschulte, A. and Strauss, $\mathrm{H} .:$ The sulfur isotopic evolution of Phanerozoic seawater based on analysis of structurally substituted sulfate in carbonates, Chem. Geol. , 204, 255-286, 2004.

Kasting, J. F. and Siefert, J. L.: Life and the evolution of Earth's atmosphere, Science, 296, 1066-1068, 2004.

30 Kemp, A. I. S., Hawkesworth, C. J., Paterson, B. A., and Kinny, P.: Episodic growth of the Gondwana Supercontinent from hafnium and oxygen isotopes in zircon, Nature, 439, 580583, 2006.

Kennedy, M., Droser, M., Meyer, L. M., Pevear, D., and Mrofka, D.: Late Precambrian oxygena-

$2,69-84,2007$

\section{A normalised \\ seawater strontium \\ isotope curve}

G. A. Shields

\section{Title Page}

Abstract

Introduction

Conclusions

References

Tables

Figures

I

14

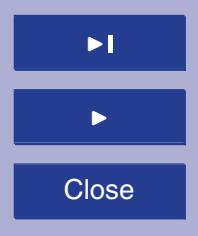

Back

Close

Full Screen / Esc

Printer-friendly Version

Interactive Discussion 
tion: inception of the clay mineral factory, Science 311, 1446-1449, 2006.

Kirschvink, J.L., Ripperdan, R. L., and Evans, D. A. D.: Evidence for a large-scale reorganization of Early Cambrian continental masses by inertial interchange true polar wander, Science, 277, 541-545, 1997.

5 Lenton, T. M.: The role of land plants, phosphorus weathering and fire in the rise and regulation of atmospheric oxygen, Global Change Biology, 7, 613-629, 2001.

Lenton, T. M. and Watson, A. J.: Redfield revisited 1: Regulation of nitrate, phosphate and oxygen in the ocean, Global Biogeochem. Cycles, 14, 225-248, 2000.

Lenton, T. M. and Watson, A. J.: Biotic enhancement of weathering, atmospheric oxygen and carbon dioxide in the Neoproterozoic, Geophys. Res. Lett., 31, L05202, doi:10.1029/2003GL018802, 2004.

McCulloch, M. T.: Primitive ${ }^{87} \mathrm{Sr} /{ }^{86} \mathrm{Sr}$ from and Archean barite and conjecture on the Earth's age and origin, Earth Planet. Sci. Lett., 126, 1-13, 1994.

O'Nions, R. K., Evenson, N. M., and Hamilton, P. J.: Geochemical modelling of mantle differentiation and crustal growth, J. Geophys. Res., 84, 6091-6101, 1979.

Peucker-Ehrenbrink, B. and Miller, M. W.: Marine ${ }^{87} \mathrm{Sr} /{ }^{86} \mathrm{Sr}$ record mirrors the evolving upper continental crust, Geochim. Cosmochim Acta, 70, 18, A487, 2006.

Palmer M. R. and Edmond, J. M.: Strontium isotope budget of the modern ocean, Earth Planet. Sci. Lett., 92, 11-26, 1989.

20 Rowley, D.: Rate of plate creation and destruction, Geol. Soc. Am. Bull., 114, 927-933, 2002.

Shields, G. A., Stille, P., and Brasier, M. D.: Isotopic records across two phosphorite giant episodes compared: the Precambrian-Cambrian and the late Cretaceous-recent, in: Marine authigenesis: From Global to Microbial, edited by: Glenn, C., Prévôt-Lucas, L., Lucas, J., SEPM special volume 66, p. 103-116, 2000.

Shields, G. A. and Veizer, J.: Precambrian marine carbonate isotope database: Version 1.1, Geochem., Geophys., Geosyst., 6, 1-12, 2002.

Spooner, E. T. C.: The strontium isotopic composition of seawater, and seawater-oceanic crust interaction, Earth Planet. Sci. Lett., 31, 167-174, 1976.

Squire, R. J., Campbell, I. H., Allen, C. M., and Wilson, C. J. L.: Did the Transgondwanan 30 Supermountain trigger the explosive radiation of animals on Earth?, Earth Planet. Sci. Lett., 250, 116-133, 2006.

Strauss, H.: Geological evolution from isotope proxy signals - sulphur, Chem. Geol., 161, 89$101,1999$.
2, 69-84, 2007

\section{A normalised \\ seawater strontium \\ isotope curve}

G. A. Shields

\section{Title Page}

Abstract

Introduction

Conclusions

References

Tables

Figures

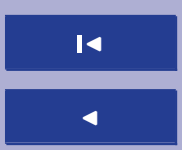

$>1$

Back

Close

Full Screen / Esc

Printer-friendly Version

Interactive Discussion 
Veizer, J. and Mackenzie, F. T.: Evolution of sedimentary rocks, in: , Treatise on geochemistry, edited by: Mackenzie, F. T. (Volume editor), Volume 7, Sediments, diagenesis, and sedimentary rocks, 369-407, 2003.

Veizer, J., Ala, D., Azmy, K., et al.: ${ }^{87} \mathrm{Sr} /{ }^{86} \mathrm{Sr}, \delta^{13} \mathrm{C}$ and $\delta^{18} \mathrm{O}$ evolution of Phanerozoic seawater, Chem. Geol., 161, 59-88, 1999.

Walker, J. C. G., Hays, P. B., and Kasting, J. F.: A negative feedback mechanism for the longterm stabilization of Earth's surface temperature, J. Geophys. Res., 86, 9776-9782, 1981.

Yuan, X., Xiao, S., and Taylor, T. N.: Lichen-like symbiosis 600 million years ago, Science, 308, 1017-1020, 2005.
2, 69-84, 2007

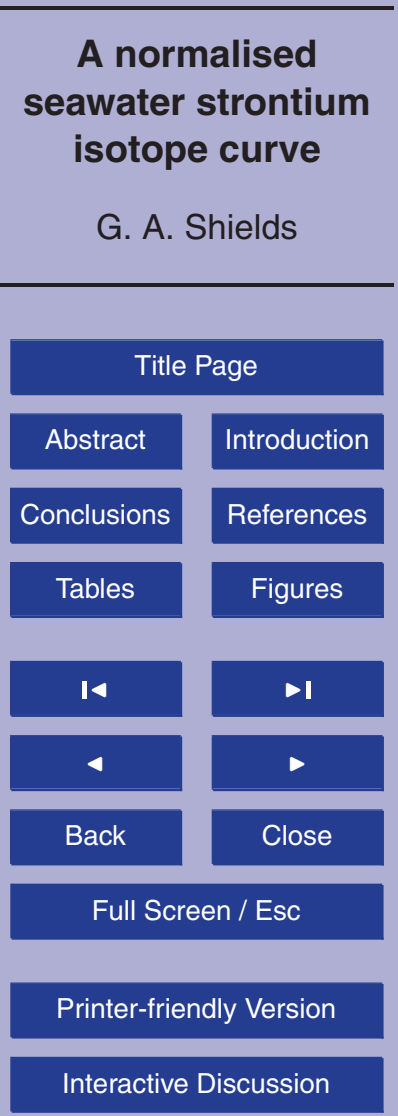

G. A. Shields 


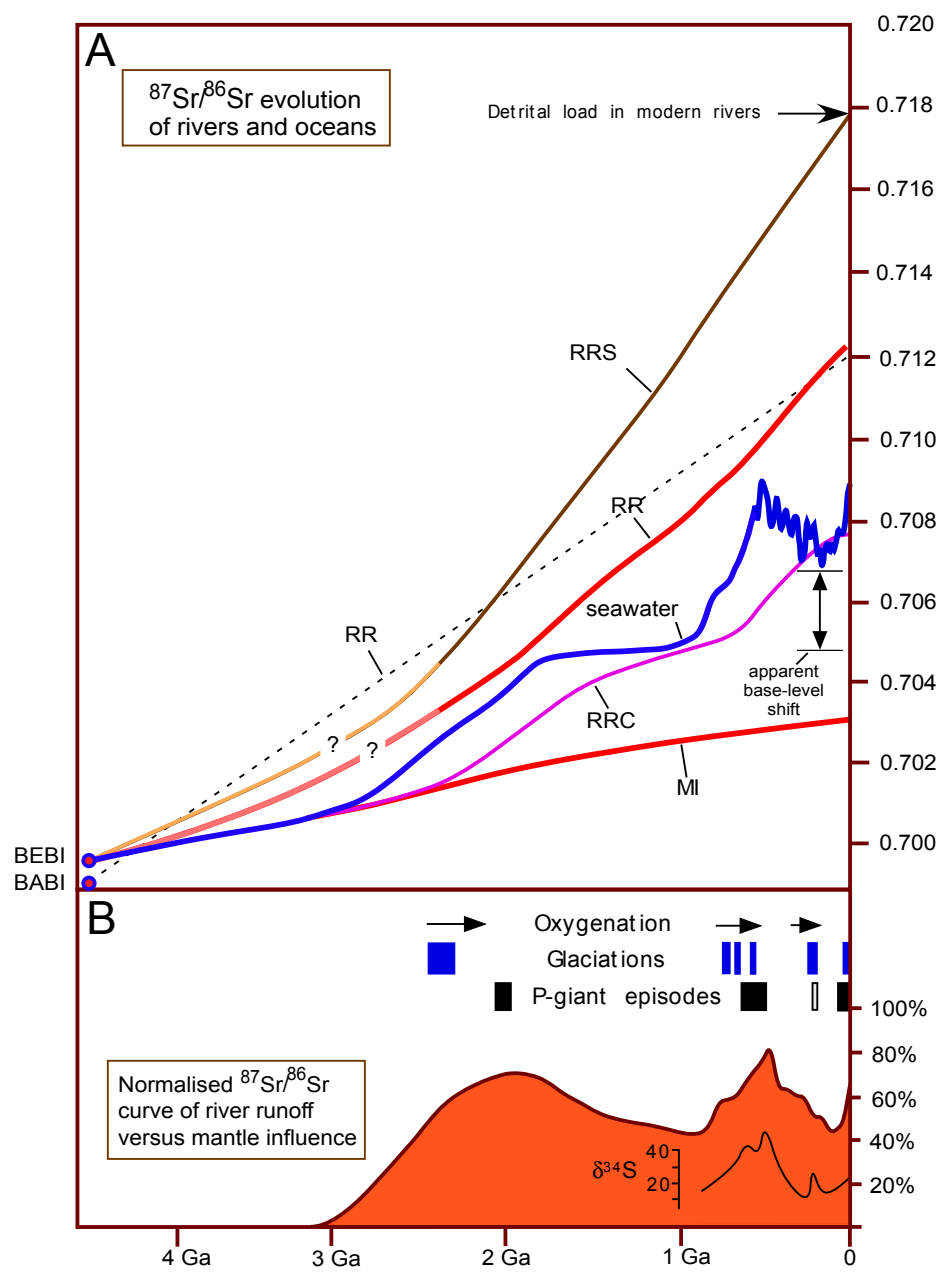

2, 69-84, 2007

\section{A normalised seawater strontium isotope curve}

G. A. Shields

\begin{tabular}{|c|c|}
\hline \multicolumn{2}{|c|}{ Title Page } \\
\hline Abstract & Introduction \\
\hline Conclusions & References \\
\hline Tables & Figures \\
\hline & \\
\hline I4 & $>$ I \\
\hline 4 & - \\
\hline Back & Close \\
\hline Full Screen / Esc
\end{tabular}

Printer-friendly Version

Interactive Discussion

Fig. 1. 
Fig. 1. Sr isotope evolution of seawater and ocean fluxes (A) and its implications for the relative influence of continental weathering on ocean composition (B). The seawater ${ }^{87} \mathrm{Sr} /{ }^{86} \mathrm{Sr}$ curve (Veizer et al., 1999; Shields and Veizer, 2002) in (A) has been constructed from the lowermost ratios for each time interval. The river runoff (RR) curve has been determined by assuming a modern-like 9:11 relationship between $\mathrm{Sr}$ input from marine carbonate weathering (RRC) and silicate weathering (RRS), respectively. The RRC curve assumes that sediments undergoing weathering have a skewed age distribution, with a mean age of $250 \mathrm{Ma}$ (PeuckerEhrenbrink and Miller, 2006), and so lags seawater ${ }^{87} \mathrm{Sr} /{ }^{86} \mathrm{Sr}$ by $>250 \mathrm{Ma}$. The RRS curve is an idealistic representation based on predicted crustal evolution (O'Nions et al., 1979), other authors assume much earlier crustal $\mathrm{Rb} / \mathrm{Sr}$ differentiation with minimal isotopic evolution (Kamber and Webb, 2001). Ocean crust alteration provides less radiogenic Sr to the oceans (MI). The curve in (B) assumes that seawater ${ }^{87} \mathrm{Sr} /{ }^{86} \mathrm{Sr}$ results from simple binary mixing between RR and $\mathrm{MI}$, and shows that the influence of continental weathering was less prior to $2.5 \mathrm{Ga}$, and negligible prior to $3.0 \mathrm{Ga}$. The normalised ${ }^{87} \mathrm{Sr} /{ }^{86} \mathrm{Sr}$ and seawater $\delta^{34} \mathrm{~S}$ curves (Kampschulte and Strauss, 2004; Hough et al., 2006) have been smoothed by plotting values for every 50 million years only. P-giant episodes (Shields et al., 2000).

\section{A normalised seawater strontium isotope curve}

G. A. Shields

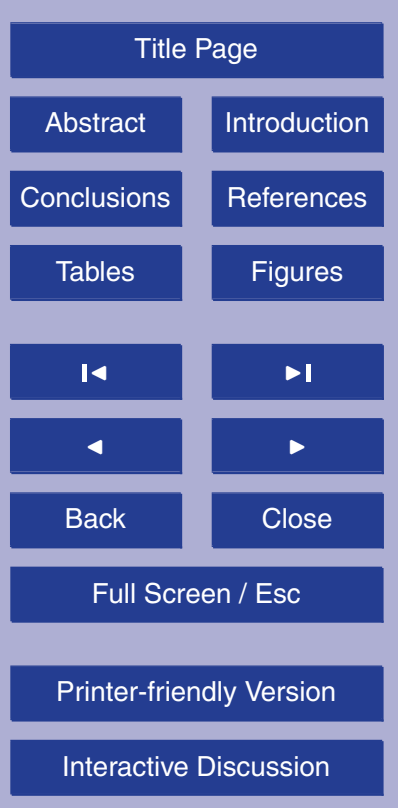

